\title{
Experimental culture of black tiger shrimp Penaeus monodon Fabricius, 1798 in open sea floating cage
}

\author{
G. MAHESWARUDU*, G. SYDA RAO, SUBHADEEP GHOSH, RITESH RANJAN, \\ BISWAJIT DASH, P. MUTHUKRISHNAN AND S. VEENA \\ Visakhapatnam Regional Centre of ICAR-Central Marine Fisheries Research Institute, Visakhapatnam - 530003 \\ Andhra Pradesh, India \\ *ICAR-Central Marine Fisheries Research Institute, P. B. No. 1603, Ernakulam North P. O., Kochi, Kerala, India \\ e-mail:maheswarudu@yahoo.com
}

\begin{abstract}
An experiment was designed and conducted to assess the feasibility for culture of Penaeus monodon in $6 \mathrm{~m}$ dia HDPE circular floating cage, installed at 10-12 m depth off Visakhapatnam in the Bay of Bengal. The cage was fixed with three cylindrical nets; inner net of $2 \mathrm{~mm}$ mesh $\left(6 \mathrm{~m}\right.$ dia $\times 5.5 \mathrm{~m}$ height) to rear post-larvae from stock to $80^{\text {th }}$ day; middle net of $10 \mathrm{~mm}$ mesh $(6 \mathrm{~m} \times 5.5 \mathrm{~m})$ to rear juveniles from day 81 onwards and an outer net of $40 \mathrm{~mm}$ mesh $(8 \mathrm{~m}$ dia $\times 4.5 \mathrm{~m}$ height $)$ to prevent entry of predators. Post-larvae $\left(\mathrm{PL}_{23}\right)$ of P. monodon (mean total length $16.1 \pm 3.8 \mathrm{~mm}$ ), were stocked in the cage at a density of $\left.1179 \mathrm{PL} \mathrm{m}^{-3}\right)$. Bottom water parameters viz., salinity, temperature, dissolved oxygen, $\mathrm{pH}$ and ammonia $\left(\mathrm{NH}_{3}-\mathrm{N}\right)$ recorded in the cage site during the culture period were $34-35 \mathrm{ppt}, 26-32^{\circ} \mathrm{C}, 3.9-4.6 \mathrm{ml} \mathrm{l}^{1-1}, 8.1-8.3$ and $0.05-0.07 \mathrm{mg} \mathrm{l}^{1-1}$, respectively. Shrimp feed varying in size suitable to different growth stages, was used during the trial. Feed was given twice during the first 20 days and thrice during 21-99 days. Feeding rate per day ranged from $133.3 \%$ of the biomass of shrimp at stocking time to $3.1 \%$ of the biomass of shrimp at preharvest. P. monodon registered a growth rate of $0.87 \mathrm{~mm}$ $(\mathrm{TL}) / 0.018 \mathrm{~g}$ (wt) per day during first 30 days; $0.89 \mathrm{~mm} / 0.069 \mathrm{~g}$ per day during $31-60$ days and $0.37 \mathrm{~mm} / 0.051 \mathrm{~g}$ per day during 61-90 days. On day 100, about $207 \mathrm{~kg}$ of shrimp (production rate, $1.62 \mathrm{~kg} \mathrm{~m}^{-3}$ ) was harvested and the mean size of harvested shrimp was $81.54 \pm 15.20 \mathrm{~mm}$ TL/4.50 $\pm 2.80 \mathrm{~g}$ wt. Survival recorded was $31.4 \%$ and the feed conversion ratio (FCR) was 3.97. Present study demonstrated the possibility for culture of P. monodon in open sea floating cage. The possible causes for low survival and high FCR are discussed.
\end{abstract}

Keywords: Black tiger shrimp, Cage culture, Open sea floating cage, Penaeus monodon

\section{Introduction}

The black tiger shrimp Penaeus monodon is the most suitable species for shrimp culture due to its fast growth and adaptability to a wide range of salinity (FAO, 2015a). In India tiger shrimp was adopted by shrimp farmers all along the coast as it fetches high returns compared to other cultivable shrimp species such as Feneropenaeus indicus and Penaeus semisulcatus. Though culture of tiger shrimp started much earlier, it reached the peak in the nineties after establishment of 232 shrimp hatcheries for substantial production of seed (FAO, 2015b). But shrimp culture industry faced serious setback due to eruption of the dreaded disease caused by white spot syndrome virus (WSSV) since 1995-96. WSSV becomes more virulent and flare up when shrimp is subjected to stress conditions and the disease is the main hindrance for the shrimp culture industry as shrimp farmers are adopting high density practices to obtain more profits (Mohan, 1996). Alternatives to avoid disease in shrimp culture are to opt for flow-through system and open sea cage/pen culture systems to reduce stress by facilitating free flow of fresh seawater. Tiger shrimp being bottom dweller and burrower is most suitable for pen culture. But pen culture requires shallow, calm backwaters, which are very limited along the Indian coast. India has a vast coastline of $8,129 \mathrm{~km}$ and a continental shelf of $3,72,424 \mathrm{~km}^{2}$, which are potential sites to undertake open sea cage culture. Nursery rearing of $P$. monodon post-larvae for a period of 20 days with $60 \%$ survival at a stocking density of 5,000-10,000 $\mathrm{PL}_{8-10}$ $\mathrm{m}^{-3}$, in floating cages $(2 \times 5 \times 1.5 \mathrm{~m})$ moored in protected bays was reported by De la Pena (1985). Angell (1992) reported nursery rearing of $P$. monodon from fry (wild collection) to post-larvae in floating cages $(3 \times 2 \times 1 \mathrm{~m})$ erected in ponds, for a period of 20 days with $6.6-72.1 \%$ survival at stocking density $61-9,410$ fry $\mathrm{m}^{-3}$. Nursery rearing of post-larvae of $P$. monodon in floating cages $(0.5 \times 0.5 \times 0.5 \mathrm{~m})$ placed in a pond for a period of 30 days with $65-78 \%$ survival at stocking density $100-400 \mathrm{PL} \mathrm{m}^{-2}$ was reported by Sajidkhan and Hukam Singh (2005). P. mondon was cultured for 60 days (1.5 to $17.8 \mathrm{~g}$ ) at a density of 22 seeds $\mathrm{m}^{-2}$ in a rectangular cage $(5 \times 4 \times 1 \mathrm{~m})$ 
erected in Vellar Estuary (Shanmugam et al., 1994). Culture of pink shrimp Farfantepenaeus brasiliensis (1.15 to $7.93 \mathrm{~g}$ ) was studied at three stocking densities (10 shrimp $\mathrm{m}^{-2}, 20$ shrimp $\mathrm{m}^{-2}$ and 40 shrimp $\mathrm{m}^{-2}$ ) in 4 $\mathrm{m}^{2}$ cages in the Patos Lagoon Estuary in southern Brazil for a period of 65 days which reported higher production

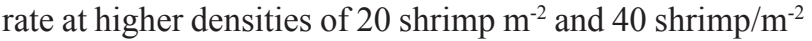
(Sílvio Peixoto, 2013). Culture of F. indicus (3.1-22.1 g) in rectangular $(10 \times 5 \times 1.5 \mathrm{~m})$, square $(7 \times 7 \times 1.5 \mathrm{~m})$ and circular $(7.98 \mathrm{~m}$ dia $\times 1.5 \mathrm{~m})$ cages erected in Vellar Estuary for a period of 100 days at 20 shrimp $\mathrm{m}^{-2}$ density found that rectangular cage yielded higher survival, growth and production rate (Sivanandavel and Soundarapandian, 2013a). Experimental study of culture of $F$. indicus (postlarva to $14.7 \mathrm{~g}$ ) stocked at $20 \mathrm{PL} \mathrm{m}^{-2}$ in rectangular cages $(10 \times 4 \times 1 \mathrm{~m})$ erected on the bottom soil substrate $v s 30 \mathrm{~cm}$ above the bottom soil substrate in Vellar Estuary, showed higher growth, survival rate and production rate from the cages erected on the bottom soil substrate (Sivanandavel and Soundarapandian, 2013b). Growth studies at different densities (13 and 21 shrimp $\mathrm{m}^{-2}$ ) with different feeds and maturation studies with different broodstock diets, on green tiger shrimp $P$. semisulcatus was conducted in bottom set cages $(1 \times 0.75 \times 0.5 \mathrm{~m})$ in the Gulf of Mannar (Maheswarudu et al., 2011; Maheswarudu and Vineetha, 2013). Paquotte et al. (1998) reported on intensive culture of Litopenaeus vannamei (at 625-2500 $\mathrm{m}^{-2}$ density) in floating cages $(5.5 \times 2.8 \times 1 \mathrm{~m})$ in estuarine zone. As no information is available on culture of $P$. monodon in open sea floating cage, an attempt was made to explore the feasibility of tiger shrimp as a candidate for cage culture using large volume $\left(127 \mathrm{~m}^{3}\right)$ circular floating cage at higher stocking density of $1179 \mathrm{PL} \mathrm{m}^{-3}$ deployed at 10 $12 \mathrm{~m}$ depth, in the Bay of Bengal off Visakhapatnam in Andhra Pradesh. The present study is the first report on culture of $P$. monodon in open sea floating cage.

\section{Materials and methods}

\section{Location of the experiment}

The study was conducted during April - July 2009 in the Bay of Bengal off Visakhapatnam. One $6 \mathrm{~m}$ dia HDPE circular floating cage was installed off Visakhapatnam in

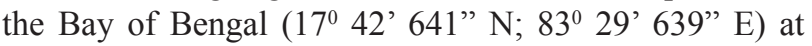
$10-12 \mathrm{~m}$ depth for the present study. Bottom of the sea was rocky and sandy at the cage culture site.

\section{Cage}

Circular cage frame was fabricated using HDPE pipes of different diameters. Two rings, one $6 \mathrm{~m}$ dia and the other $8 \mathrm{~m}$ dia, were made with $160 \mathrm{~mm}$ dia pipe. Both the rings were connected horizontally by 8 pieces of $1 \mathrm{~m}$ length pipe of $250 \mathrm{~mm}$ dia, at equal distance, for providing base support. The third ring, made of $90 \mathrm{~mm}$ dia pipe, was fixed in between two rings, slightly close to the outer ring for the catwalk. A $6 \mathrm{~m}$ dia (fourth) ring made of $90 \mathrm{~mm}$ pipe was fixed to the base rings at a height of $1 \mathrm{~m}$ by connecting all 8 pieces of $250 \mathrm{~mm}$ dia pipes by 8 vertical and 8 tangential pipes of $90 \mathrm{~mm}$ dia (Fig. 1).

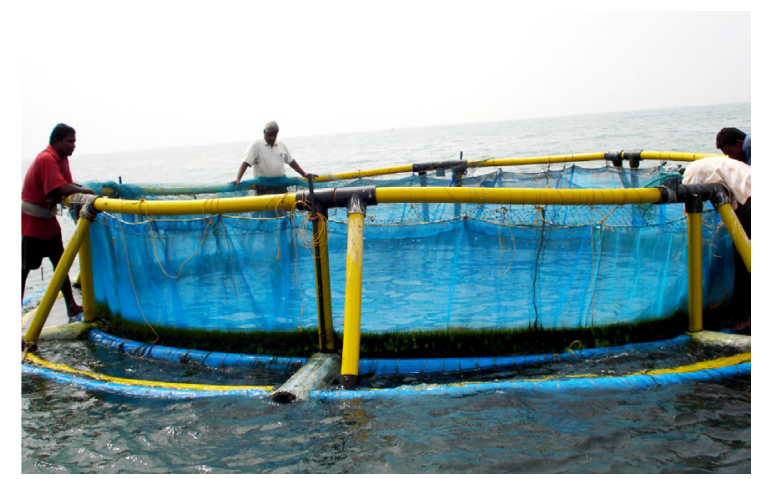

Fig. 1. View of $6 \mathrm{~m}$ dia cage installed in the Bay of Bengal for culture of $P$. monodon

Net

The outer, middle, inner and bird nets were made with nylon webbing of different mesh sizes. Outer net was cylindrical in shape with $8 \mathrm{~m}$ dia and $4.5 \mathrm{~m}$ height. The top line was fixed to outer ring of cage frame and the bottom line fixed to ballast ring to retain the cylindrical shape. The outer net of $40 \mathrm{~mm}$ mesh size was provided to avoid entry of predators. Middle net was cylindrical in shape with $6 \mathrm{~m}$ dia and $5.5 \mathrm{~m}$ height, with mesh size of $10 \mathrm{~mm}$. The top line was tied to fourth ring that was fixed at one meter height of the cage base frame. Inner net was similar to middle net in dimensions, but was made with $2 \mathrm{~mm}$ mesh velon screen, Post-larvae were stocked and reared for a period of 80 days in the inner net and subsequently reared in the middle net from day 81 onwards. Sinkers were fixed to the inner net to facilitate resting on the middle net. Bird net was circular shape nylon webbing of $6 \mathrm{~m}$ dia with $50 \mathrm{~mm}$ mesh size, which was tied to the top ring of the cage to avoid predation by birds. Ballast pipe $(8 \mathrm{~m}$ dia ring) made up of $50 \mathrm{~mm}$ dia HDPE pipe and filled with granite chips to increase the weight, was tied at the bottom line of outer net to retain the net shape against water current and waves.

\section{Mooring}

A gabion box of $3 \times 2 \times 3 \mathrm{~m}$ was filled with $3.5 \mathrm{t}$ of granite stones and was lowered at 10-12 $\mathrm{m}$ depth. The cage was moored with the gabion box with support of two lines, one $32 \mathrm{~mm}$ polypropylene rope and the other $16 \mathrm{~mm}$ iron chain. Three floats were fixed to mooring line; one at $12 \mathrm{~m}$ height (from gabion box) near swivel to facilitate free rotation of cage as per the current direction; two between 
swivel and cage with shock absorber to protect the cage against the wave force (Suresh Kumar et al., 2012; Ritesh Ranjan et al., 2014).

\section{Seed}

A total of 1.5 lakh $\mathrm{PL}_{23}$ of P. monodon, procured from a local commercial hatchery, subjected to WSSV test and formalin test, were released into the cage.

\section{Feed}

Commercial shrimp feed (C. P. Aquaculture Private Ltd.) was used in this trial. During the first 20 days, feed was given twice a day, once in the morning (08.00 hrs) and evening (17.00 hrs). From day 21 onwards feed was given thrice a day, morning (08.00 hrs), afternoon (13.00 hrs) and evening (17.00 hrs). Type of feed and quantity of feed given per one lakh post-larvae per day during different periods of culture are given in Table 1. The feed was broadcasted in the cage at feeding time and feed consumption was checked after $2 \mathrm{~h}$ of every feeding time (2-3 times per day) by two persons lifting the inner net slowly and the feed quota for subsequent day was adjusted accordingly. No check tray was used to assess feed consumption and this method has given a comprehensive picture of feed consumption. Details of feed consumption in relation to the size of the shrimp during different periods of culture, the total biomass of the standing shrimp population based on assumed survival and calculated feeding rates for different periods of grow-out culture are given in Table 2. For calculation of feeding rates at different periods of culture, assumed survival rate for different periods was taken into account, which was estimated based on the back calculation method, by the addition of $11.5 \%$ survival rate to the recorded survival rate at the harvest for every fortnight of the preceding period of culture. Thus the assumed survival rates estimated were: $42.9 \%$ after 90 days; $54.4 \%$ after 75 days; $65.9 \%$ after 60 days; $77.4 \%$ after 45 days and $88.9 \%$ after 30 days. The assumed survival rate, arrived after 30 days (88.9\%) was quite reasonable (Table 3 ).

\section{Sampling}

Sampling for assessing growth was done for the first time after 30 days of culture and subsequently after every fortnight. While sampling, inner net was slowly lifted and shrimps were scooped for measuring total length and weight. About 25 animals were measured individually for total length $(\mathrm{mm})$ on every sampling and mean total length

Table 1. Type of feed, feeding schedule adopted and total quantity of feed consumed during different periods of growout culture of $P$. monodon in open sea floating cage

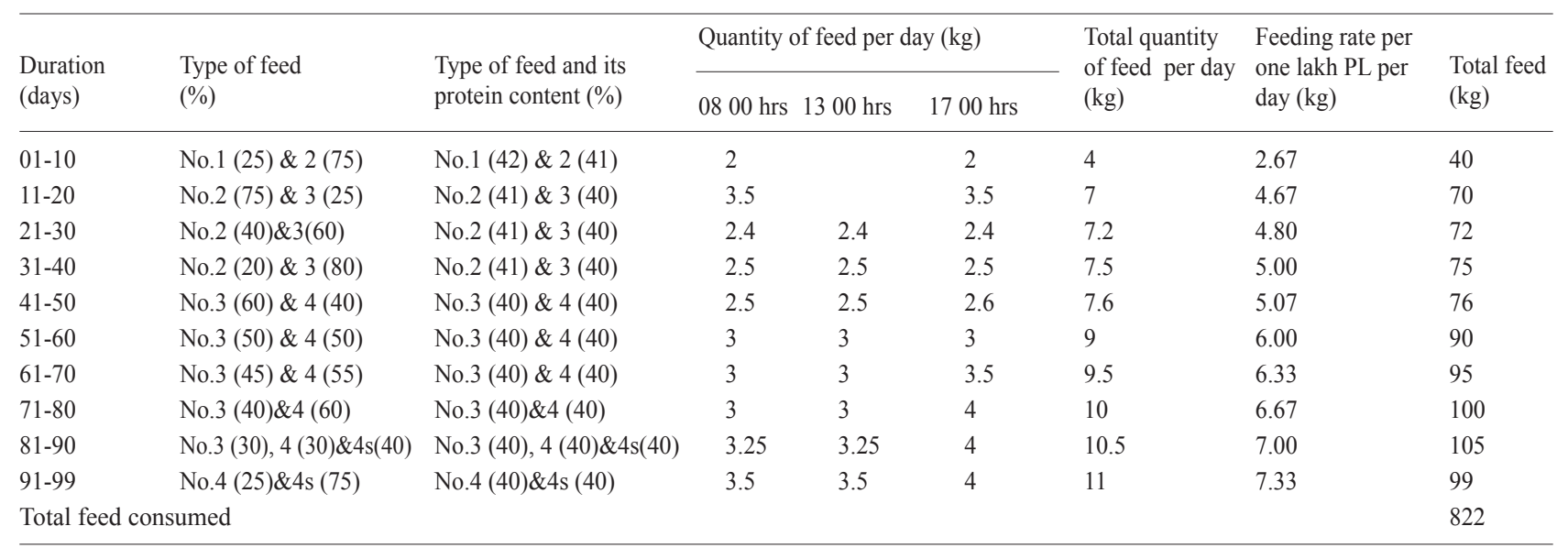

Table 2. Calculated feeding rate (\% of the standing biomass of the shrimp population) based on the assumed survival and biomass of the standing shrimp population of $P$. monodon cultured in open sea floating cage

\begin{tabular}{|c|c|c|c|c|c|c|}
\hline $\begin{array}{l}\text { Duration } \\
\text { (days) }\end{array}$ & $\begin{array}{l}\text { Stocked/Assumed } \\
\text { population } \\
\text { (number) }\end{array}$ & $\begin{array}{l}\text { Assumed } \\
\text { survival }(\%)\end{array}$ & $\begin{array}{l}\text { Mean weight } \\
(\mathrm{g})\end{array}$ & $\begin{array}{l}\text { Standing } \\
\text { biomass }(\mathrm{kg})\end{array}$ & $\begin{array}{l}\text { Feed consumed } \\
\text { per day }(\mathrm{kg})\end{array}$ & $\begin{array}{l}\text { Computed feeding } \\
\text { rate per day ( } \% \text { of } \\
\text { standing biomass) }\end{array}$ \\
\hline Stocking time & 150000 & 100 & 0.030 & 4.5 & 6 & 133.3 \\
\hline $31-45$ & 133350 & 88.9 & 0.590 & 78.7 & 7.6 & 9.7 \\
\hline $46-60$ & 116100 & 77.4 & 1.383 & 160.6 & 8.53 & 5.3 \\
\hline $61-75$ & 98850 & 65.9 & 2.687 & 265.6 & 9.66 & 3.6 \\
\hline $76-90$ & 81600 & 54.4 & 4.130 & 337.0 & 10.33 & 3.1 \\
\hline $91-99$ & 64350 & 42.9 & 4.230 & 272.2 & 11 & 4.0 \\
\hline Survival at harvest & & 31.4 & & & & \\
\hline
\end{tabular}


Table 3. Details of bottom water parameters at cage culture site during culture period

\begin{tabular}{llllll}
\hline $\begin{array}{l}\text { Duration } \\
\text { (days) }\end{array}$ & $\begin{array}{l}\text { Temperature } \\
\left({ }^{\circ} \mathrm{c}\right)\end{array}$ & $\begin{array}{l}\text { Salinity } \\
(\mathrm{ppt})\end{array}$ & $\begin{array}{l}\text { Dissolved oxygen } \\
\left(\mathrm{ml} \mathrm{1} 1^{-1}\right)\end{array}$ & $\mathrm{pH}$ & $\begin{array}{l}\text { Ammonia } \\
\left(\mathrm{mg} \mathrm{l}^{-1}\right)\end{array}$ \\
\hline Stocking time & 27.9 & 35 & 3.91 & 8.2 & 0.05 \\
$31-60$ & 31.8 & 35 & 4.33 & 8.2 & 0.06 \\
$61-90$ & 32.1 & 35 & 4.36 & 8.3 & 0.07 \\
$91-100$ & 26.2 & 34 & 3.98 & 8.1 & 0.07 \\
\hline
\end{tabular}

was computed. Total weight of all 25 animals sampled for total length, was recorded with field balance, from which mean weight $(\mathrm{g})$ was computed. Specific growth rate in terms of total length and weight per day was computed for every month (Mean total length/weight at sampling Mean total length/ weight of previous sampling)/rearing days).

\section{Water parameters}

Bottom water samples were collected once in a month near cage culture site and analysed in the laboratory for dissolved oxygen, $\mathrm{pH}$ and ammonia. Bottom water temperature and salinity were recorded on site immediately after collecting water sample. Temperature was recorded using a thermometer (Jensen Deluxe). Salinity was recorded using an Atago hand refractometer. $\mathrm{PH} /$ Ion/Conductivity meter (Eutech Instruments, PC, 5500) was used to measure water $\mathrm{pH}$. Dissolved oxygen was estimated following Winkler method and ammonia was measured following phenol hypochlorite method (Zolarzano, 1969).

\section{Cage and net management}

Frequent visits were made to cage site to observe shrimp behaviour as well as net conditions. The mooring was checked by a skin diver once in every month and necessary precautions were taken to ensure that the cage with the gabion box is intact. Due to settling of algae on the inner net up to the light penetration point, periodical cleaning was required to facilitate free flow of water. Hence once in a week the inner net was cleaned with a nylon brush and it was replaced every 30 days. The inner net with settled algae and fouling organisms was sun dried and cleaned for subsequent replacement.

\section{Harvest}

On day 100, the inner net was lifted and the shrimps were scooped and brought to the shore. Total weight of shrimp harvested, sexwise length and weight measurements of individual shrimp were recorded in the Mariculture laboratory, Visakhapatnam Regional Centre of ICAR-Central Marine Fisheries Reaearch Institute, Visakhapatnam. About one $\mathrm{kg}$ of shrimp was taken randomly from the harvested shrimp and counted, which was raised to the total quantity of shrimp harvested. Survival rate $(\%)$ was calculated considering the total number of shrimps harvested from the stocked seed (1.5 lakhs). The one kg sample was also used for recording sex ratio, and individual length and weight measurements. Total length $(\mathrm{mm})$ and weight $(\mathrm{g})$ of males $(\mathrm{n}=71)$ and females $(n=157)$ were measured and length-weight relationship was computed for both sexes separately following standard method (Le Cren, 1951). Length-weight relationship parameters such as ' $a$ ' and ' $b$ ' were computed using the least square regression on the log transformation of the equation: $\mathrm{W}=\mathrm{aL}$. Slopes ( $\mathrm{b}$ values) for the length-weight relationship between sexes were compared using ANCOVA (Snedecor and Cochran, 1980). Fulton's condition factor $(\mathrm{K})$ of the shrimps for both sexes was estimated from mean length and the mean weight in the sample using the relationship, $\mathrm{K}=100 \mathrm{~W} / \mathrm{L}^{3}$, where $\mathrm{K}=$ condition factor, $\mathrm{W}=$ mean weight of shrimp $(\mathrm{g})$, and $\mathrm{L}=$ mean length of shrimp $(\mathrm{cm})$. Total quantity $(\mathrm{kg})$ of feed given during the 99 days of culture was summed up and FCR was calculated by dividing with total quantity (kg) of shrimp harvested.

\section{Results and discussion}

\section{Water parameters}

Details of bottom water parameters such as temperature, salinity, dissolved oxygen, $\mathrm{pH}$ and ammonia during different periods of cage culture are presented in Table 3. Water temperature during stocking time (April) was low and it increased in May and June and came down in July. Salinity was at 35 ppt during stocking time which dropped to $34 \mathrm{ppt}$ at the time of harvest. Dissolved oxygen ranged between 3.91 and $4.36 \mathrm{ml} \mathrm{l}^{-1}$; $\mathrm{pH}$ between 8.1 and 8.3 and ammonia between 0.05 and $0.07 \mathrm{mg} \mathrm{l}^{-1}$.

\section{Shrimp behaviour}

During the first 30 days, shrimps were found swimming in circular motion just before feeding but after feed broadcasting they slowly moved to the bottom. From day 40 onwards shrimps came to surface, but clung to the wall of inner net just before feeding and after feed was given, slowly moved to the bottom. From day 45 onwards, as shrimp grew, they were found consuming feed by attaching to wall of inner net, may be to use available 
surface area. It was observed that as shrimp grew, it used net wall area for clinging/resting due to limited availability of bottom area.

Growth

Growth performance of $P$. monodon, in terms of length $(\mathrm{mm})$ and weight $(\mathrm{g})$, in the floating cage during the experimental period is presented in Table 4 .

Table 4. Growth performance of $P$. monodon in open sea floating cage during culture period

\begin{tabular}{lll}
\hline $\begin{array}{l}\text { Duration } \\
\text { (days) }\end{array}$ & $\begin{array}{l}\text { Total length }(\mathrm{mm}) \\
(\text { Mean } \pm \mathrm{SD})\end{array}$ & $\begin{array}{l}\text { Mean weight } \\
(\mathrm{g})\end{array}$ \\
\hline Stocking time & $16.1 \pm 3.8$ & 0.030 \\
30 & $42.16 \pm 9.95$ & 0.590 \\
45 & $55.6 \pm 20.7$ & 1.383 \\
60 & $69.0 \pm 3.03$ & 2.687 \\
75 & $79.36 \pm 3.54$ & 4.130 \\
90 & $80.02 \pm 4.13$ & 4.230 \\
100 & $81.54 \pm 15.20$ & $4.50 \pm 2.80$ \\
\hline
\end{tabular}

$P$. monodon registered a mean growth rate of $0.87 \mathrm{~mm} / 0.018 \mathrm{~g}$ per day during first 30 days; $0.89 \mathrm{~mm}$ $/ 0.069 \mathrm{~g}$ per day during 31- 60 days and $0.37 \mathrm{~mm} / 0.051 \mathrm{~g}$ per day during 61-90 days. The overall growth rate was $0.66 \mathrm{~mm} / 0.045 \mathrm{~g}$ per day during the 99 days of cage culture. Shanmugam et al. (1994) conducted an experimental study on $P$. monodon in $5 \times 4 \times 1 \mathrm{~m}$ cages erected in Vellar Estuary, at density of 12 seeds $\mathrm{m}^{-3}$ and reported growth rate of $1.03 \mathrm{~mm} / 0.27 \mathrm{~g}$ per day for 60 days experimental period. Low growth rate registered in the present study compared to that of Shanmugam et al. (1994) could be attributed to higher stocking density (1179 $\mathrm{PL} \mathrm{m} \mathrm{m}^{-3}$ ) used in the present study. Paquotte et al. (1998) conducted a feasibility study of $P$. vannamei in floating cages $(5.5 \times 2.8 \times 1 \mathrm{~m})$ in estuarine zone at different densities. In this study, post-larvae were reared for two months in nursery cages until reaching $0.5 \mathrm{~g}$ size and then transferred to growout cages. They reported that shrimps attained a size of 3 to $6 \mathrm{~g}$ after 5 weeks ( 8 weeks nursery + 5 weeks in growout cage $=13$ weeks equivalent to 99 days of present study) at stocking densities of $625-2500 \mathrm{~m}^{-2}$. In the present study, the harvested mean size of P.monodon (4.5 $\mathrm{g}$ at $1179 \mathrm{~m}^{-3}$ density) was more or less similar to that attained by $P$. vannamei in floating cage (at density of $625-2500 \mathrm{~m}^{-2}$ ). Since Paquotte et al. (1998) used $1 \mathrm{~m}$ height rectangular floating cages, his reported stocking densities per $\mathrm{m}^{2}$ are equivalent to stocking densities per $\mathrm{m}^{3}$. Hence his reported results were compared with the results of the present study. $P$. vannamei utilises entire water column, unlike $P$. monodon which prefers bottom/ substratum. $P$. vannamei has also the capacity to filter zooplankton in the water column whereas $P$. monodon prefers sedentary diet (Matthew Briggs et al., 2004). The advantageous characters of $P$. vannamei like utilising the entire water column and capacity to consume zooplankton helps it to gain good growth at higher density.

\section{Length-weight relationship}

Values of length-weight relationship parameters such as ' $a$ ' (intercept), ' $b$ ' (regression coefficient), ' $\mathrm{r}$ ', (coefficient of determination) and ' $\mathrm{N}$ ' (number of specimens measured) of males, females and pooled for both sexes are given in Table 5. Slopes (b values) did not differ significantly between sexes $(p>0.05)$. Hence, both sexes were pooled and length-weight relationship curve fitted with observed values is shown in Fig. 2. Growth is isometric (b value is 3.01 for males and 3.11 for females) in both males and females. Similar results were reported in grow-out culture of $P$. monodon by Primavera et al. (1998). However, allometric growth $(b<3.0)$ was reported in pond reared P. monodon (Gopalakrishnan et al., 2014) and variation in growth from allometric to isometric (b value $=2.45$ to 3.01 ) was reported for $P$. monodon cultured in different ecological conditions (Prasad, 2001). Hence the length-weight relationship is influenced by ecological conditions of the culture system and the recorded isometric growth of the present study indicates that the location of the cage culture site is suitable for culture of tiger shrimp in floating cages.

Condition factor is an index used to investigate the state of wellbeing of the animal and the same was computed to assess the state of wellbeing of the shrimp reared in

Table 5. Length-weight relationship parameters of $P$. monodon (55-120 $\mathrm{mm}$ total length range) cultured in open sea floating cage

\begin{tabular}{llllll}
\hline & $\mathrm{a}$ & $\mathrm{b}$ & $\mathrm{r}^{2}$ & $\mathrm{~N}$ & $\mathrm{~K}$ \\
\hline Males & 0.00000683 & 3.01 & 0.98 & 71 & 0.821 \\
Females & 0.00000455 & 3.11 & 0.90 & 157 & 0.656 \\
Pooled & 0.00000528 & 3.08 & 0.93 & 228 & 0.748 \\
\hline
\end{tabular}

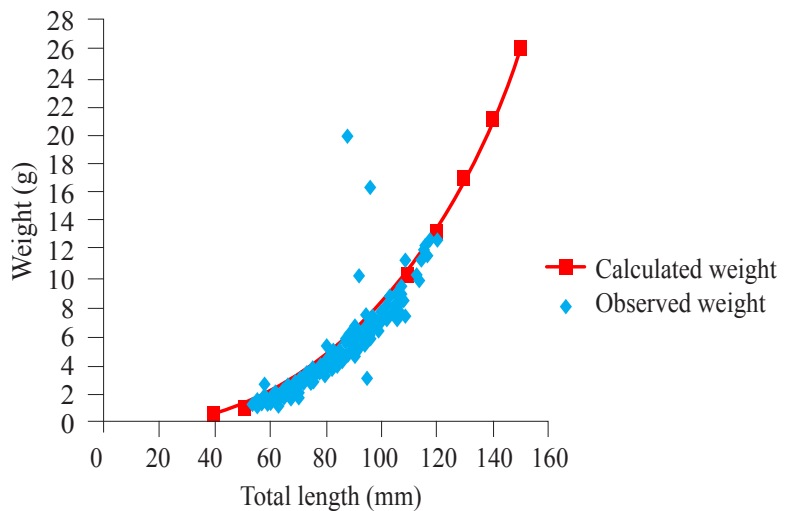

Fig. 2. Length-weight relationship curve fitted with observed values of harvested $P$. monodon in open sea floating cage 
the cage. Ajani et al. (2013) reported monthly variation in condition factor of wild P. monodon ( 0.70 to 1.05$)$ and $P$. notialis (0.70 to 0.99$)$ in Nigerian waters, implying the stock of $P$. monodon is in good physiological state of wellbeing. Gopalakrishnan et al. (2014) reported K values for pond reared male and female $P$. monodon as 0.72 and 0.78 respectively, being higher for females. Whereas in the present study, $\mathrm{K}$ values for males were 0.82 and 0.65 for females, suggesting males were healthier than females. In the present study $\mathrm{K}$ values coincided with the sex ratio (M:F=1:2.21), suggesting healthier condition of males, might be due to less survival.However, Gopalakrishnan et al. (2014) reported higher $\mathrm{K}$ values in males than females of wild P. monodon (0.98 vs 0.94) and loose shelled P. monodon (1.09 vs 1.06) in pond culture.

\section{Productivity}

After 99 days of culture, as growth did not progress much, the stock was harvested on the day 100. The total shrimp harvest was about $207 \mathrm{~kg}$. The computed FCR and production rate were 3.97 and $1.62 \mathrm{~kg} \mathrm{~m}^{-3}$ respectively. The harvested shrimp count was 228 per $\mathrm{kg}$ and survival percentage at the time of harvest was 31.4. Harvested size of shrimp was $81.54 \pm 15.20 \mathrm{~mm}$ TL/4.50 $\pm 2.80 \mathrm{~g}$ wt. Harvested size for male was $79.38 \pm 17.67 \mathrm{~mm} / 4.19 \pm 2.92 \mathrm{~g}$ and for female it was $82.52 \pm 13.89 \mathrm{~mm} / 4.65 \pm 2.75 \mathrm{~g}$ (Fig. 3). Length frequency of harvested P. monodon is given in Table 6 . The total length range was $55-120 \mathrm{~mm}$ for males and 55-117 mm for females. Among the harvested shrimp, about $63 \%$ of males and $60 \%$ of females were below $85 \mathrm{~mm}$ total length, resulting in $61.3 \%$ of total harvested animals being below $85 \mathrm{~mm}$ total length. Though harvested

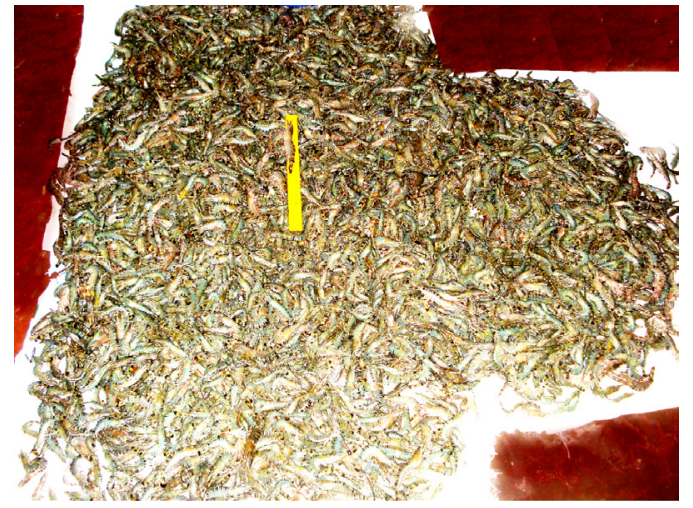

Fig. 3. Harvested P. monodon from open sea floating cage

size of shrimp ranged from 55-120 mm TL, mean size was at $81.54 \pm 15.20 \mathrm{~mm}$ due to high representation $(61.3 \%)$ of small size groups $(<85 \mathrm{~mm} \mathrm{TL})$ than large size groups (>85 mm TL).

Low survival resulted in high FCR due to cannibalism at higher stocking density (Abdusamad and Thampi, 1994). Stocking density in the present study was $1179 \mathrm{PL} \mathrm{m}^{-3}$ and the total available substrate (net surface) area for shrimp was $113.13 \mathrm{~m}^{2}\left(28.28 \mathrm{~m}^{2}\right.$ net bottom area $+84.85 \mathrm{~m}^{2}$ net wall area), resulting in availability of net surface area of $0.75 \mathrm{~m}^{2} / 1000$ PL. Arnold et al. (2006) conducted an experimental study on intensive rearing of $\mathrm{PL}_{15}$ of $P$. monodon in $2.4 \times 1.0 \times 0.7 \mathrm{~m}$ fiberglass tanks at two densities of $1000 \mathrm{~m}^{-3}$ and $2000 \mathrm{~m}^{-3}$, for a period of 56 days with and without artificial substrates. They achieved $73.2 \%$ survival and 1.17 FCR at density of $1000 \mathrm{PL} \mathrm{m}^{-3}$ without added substrates against $88.1 \%$ survival and $0.98 \mathrm{FCR}$ with added substrates by $150 \%$.

Table 6. Sexwise length frequency of harvested P. monodon from open sea floating cage

\begin{tabular}{|c|c|c|c|c|c|c|c|}
\hline $\begin{array}{l}\text { Total length } \\
\text { group (mm) }\end{array}$ & $\begin{array}{l}\text { Males } \\
\text { (No.) }\end{array}$ & $\begin{array}{l}\% \text { of total } \\
\text { harvested } \\
\text { males }\end{array}$ & $\begin{array}{l}\text { Females } \\
\text { (No.) }\end{array}$ & $\begin{array}{l}\% \text { of total } \\
\text { harvested } \\
\text { females }\end{array}$ & $\begin{array}{l}\text { Sexes pooled } \\
\text { (No.) }\end{array}$ & $\begin{array}{l}\% \text { of total } \\
\text { harvested } \\
\text { shrimps }\end{array}$ & $\begin{array}{l}\text { Cumulative } \\
\%\end{array}$ \\
\hline $51-55$ & 2 & 2.8 & 3 & 1.9 & 5 & 2.2 & 2.2 \\
\hline $56-60$ & 12 & 16.9 & 6 & 3.8 & 18 & 7.9 & 10.1 \\
\hline $61-65$ & 7 & 9.9 & 12 & 7.6 & 19 & 8.3 & 18.4 \\
\hline $66-70$ & 8 & 11.3 & 19 & 12.1 & 27 & 11.8 & 30.3 \\
\hline $71-75$ & 6 & 8.5 & 19 & 12.1 & 25 & 11.0 & 41.2 \\
\hline $76-80$ & 4 & 5.6 & 12 & 7.6 & 16 & 7.0 & 48.2 \\
\hline $81-85$ & 7 & 9.9 & 23 & 14.6 & 30 & 13.2 & 61.4 \\
\hline $86-90$ & 5 & 7.0 & 18 & 11.5 & 23 & 10.1 & 71.5 \\
\hline $91-95$ & 9 & 12.7 & 18 & 11.5 & 27 & 11.8 & 83.3 \\
\hline $96-100$ & 0 & 0.0 & 12 & 7.6 & 12 & 5.3 & 88.6 \\
\hline $101-105$ & 6 & 8.5 & 7 & 4.5 & 13 & 5.7 & 94.3 \\
\hline $106-110$ & 0 & 0.0 & 6 & 3.8 & 6 & 2.6 & 96.9 \\
\hline $111-115$ & 3 & 4.2 & 1 & 0.6 & 4 & 1.8 & 98.7 \\
\hline $116-120$ & 2 & 2.8 & 1 & 0.6 & 3 & 1.3 & 100.0 \\
\hline Total & 71 & 100.0 & 157 & 100.0 & 228 & 100 & \\
\hline
\end{tabular}


In their study available surface area was $3.65 \mathrm{~m}^{2} / 1000$ PL without artificial substrates $\left(4.9 \mathrm{~m}^{2}\right.$ wall area $+2.5 \mathrm{~m}^{2}$ bottom area). In the present study, low survival and high FCR were due to availability of five times less substrate area $\left(0.75 \mathrm{~m}^{2} / 1000 \mathrm{PL}\right)$ compared to that of $\left(3.65 \mathrm{~m}^{2} / 1000 \mathrm{PL}\right)$. Since $P$. monodon is bottom dweller and prefers substratum, unlike $P$. vannamei which is capable of utilising the water column for living, availability of the net surface area in cage culture will play a significant role in promoting survival and subsequent FCR by providing enough surface area for resting of the shrimps. P. monodon also grazes on epiphytic biota that settles on the net surface, which promotes good FCR in cage culture.

About $60 \%$ survival was achieved during nursery rearing of $P$. monodon $\left(\mathrm{PL}_{8}\right.$ to $\left.\mathrm{PL}_{20}\right)$ at higher stocking densities of 5,000 - 10,000 PL per $\mathrm{m}^{3}$ using a floating cage in a protected area in the sea (De la Pena, 1985). In the present study too, survival was good during the first 30 days. As shrimps grew, cannibalism was noticed as they are more vulnerable to cannibalism at higher density after moulting, even after feeding ad libitum, due to congested space (Abdusamad and Thampi, 1994).

Total harvested shrimp was $207 \mathrm{~kg}$ and the resultant production rate was $1.62 \mathrm{~kg} \mathrm{~m}^{-3}$ after 99 days of cage culture. Since this is the first report on the culture of tiger shrimp in open sea floating cages, no published information is available for comparison.

Economics and profitability in shrimp culture depend upon harvesting size and FCR. Bigger harvested size fetches a higher price and better FCR (low value) reduces the expenditure on feed. In the present study, survival rate, harvested size and FCR of $P$. monodon are not comparable to those cultured in pond (Maheswarudu, 2000). However, further experiments are needed by increasing the substrate area with the provision of artificial substrates in the cage to improve survival, growth and FCR, which may promote this new venture on commercial line.

\section{Acknowledgements}

The authors are grateful to Dr. A. Gopalakrishnan, Director, ICAR-CMFRI, Kochi for encouragement. We are also thankful to the Department of Animal Husbandry, Dairying and Fisheries (DADF), Ministry of Agriculture and Farmers welfare, Government of India for financing the cage culture project.

\section{References}

Abdussamad, E. M. and Thampy, D. M. 1994. Cannibalism in the tiger shrimp Penaeus monodon Fabricius in nursery rearing phase. J. Aqua. Trop., 9: 67-75.

Ajani, E. G., Bello, O. B. and Osowo, O. 2013. Comparative condition factor of two Penaeid shrimps, Penaeus notialis (pink shrimp) and Penaeus monodon (tiger shrimp) in a coastal state, Lagos, South West Nigeria. Nat. Sci. J., 11(4): $1-3$.

Angell, C. L. 1992. Cage nursery rearing of shrimp and prawn fry in Bangladesh. $B O B P / W P / 92: 1-16$.

Arnold, S. J., Sellars, M. J., Crocos, P. J. and Coman, G. J. 2005. Intensive production of juvenile tiger shrimp Penaeus monodon: An evaluation of stocking density and artificial substrates. Aquaculture, 261: 890-896.

De la Pena, D. T., Jr., Prospero, O. Q. and Young, A. T. G. 1985. Floating cage nursery for prawn. Aquaculture technology module, no. 3. Tigbauan, Iloilo, Philippines: SEAFDEC Aquaculture Department, $35 \mathrm{pp}$

FAO 2015a. Cultured aquatic species information programme Penaeus monodon. Cultured Aquatic Species Information Programme. In: FAO Fisheries and Aquaculture Department [online]. Rome. Updated 29 July 2005 [Cited 23 October 2015]. http://www.fao.org/fishery/culturedspecies/Penaeus monodon/en.

FAO 2015b. National aquaculture sector overview - India. National Aquaculture Sector Overview Fact Sheets. In: FAO Fisheries and Aquaculture Department [online]. Rome. Updated 4 April 2014. [Cited 23 October 2015]. http:// www.fao.org/fishery/countrysector/naso_india/en.

Gopalakrishnan, A., Rajkumar, M., Rahman, M. M., Sun, J., Antony, P. J., Venmathi maran, B. A. and Trilles, J. P. 2014. Length-weight relationship and condition factor of wild, grow-out and 'loose-shell affected' giant tiger shrimp, Penaeus monodon (Fabricius, 1798) (Decapoda: Penaeidae). J. Appl. Ichthyol., 30: 251-253.

Le Cren, E. D. 1951. The length-weight relationships and seasonal cycle in gonad weight and condition in the perch (Perca fluviatilis). J. Anim. Ecol., 20: 201-219. doi: $10.2307 / 1540$

Maheswarudu, G. 2000. Shrimp culture during 19982000 at marine fish farm, Regional Centre of Central Marine Fisheries Research Institute, Mandapam Camp. In: Victor, A.C.C., Kaliaperumal, N., Kandasami, D. Maheswarudu, G., Rajendran, I. Jagadis, I., Boby Ignatius, Kalimuthu, S., Edwin Joseph, V. and Rajan, G. K. (Ed.), Souvenir 2000 National Symposium on Eco-Friendly Mariculture Technology Packages - An Update. Central Marine Fisheries Research Institute, Mandapam, p. 36-39.

Maheswarudu, G. and Vineetha, Aravind 2013. Littoral Oligochaete Pontodrilus bermudensis Beddard: A potential source for Arachidonic acid that stimulates maturation in penaeid shrimp. J. Vet. Sci. Photon, 114: 290-300.

Maheswarudu, G., Radhakrishnan, E. V., Arputharaj, M. R. and Mohan, S. 2011. Growth performance of the green tiger prawn Penaeus semisulcatus De Haan in cages in the Gulf of Mannar off Mandapam, south-east coast of India. Asian Fish. Sci., 24: 100-114. 
Matthew Briggs, Simon Funge-Smith, Rohana Subasinghe and Michael Phillips. 2004. Introductions and movement of Penaeus vannamei and Penaeus stylirostris in Asia and the Pacific. RAP publication 2004/10:1-32.

Mohan, C. V., 1996. Health management strategy for a rapidly developing shrimp industry an Indian perspective In: Subasinghe, R. P., Arthur, J. R., Shariff, M. (Eds.), Health management in Asian aquaculture. FAO Fisheries Technical Paper, 360, FAO, Rome, 142: p. 75-87.

Paquotte, P., Chim, L., Martin, J.-L. M., Lemos, E., Stern, M. and Tosta, G. 1998. Intensive culture of shrimp Penaeus vannamei in floating cages: zootechnical, economic and environmental aspects. Aquaculture, 164: 151-166.

Prasad, G. 2001. Length-weight relationships of Penaeus monodon reared in semi-intensive culture systems of Kerala, India. Naga, ICLARM Q., 24: 1.

Primavera, J. H., Parado-Estepa, F. D. and Lebata, J. L. 1998. Morphometric relationship of length and weight of giant tiger prawn Penaeus monodon according to life stage, sex and source. Aquaculture, 164: 67-75.

Ritesh Ranjan, Biji Xavier, Biswajit Dash, Loveson Edward, Maheswarudu, G. and Syda Rao, G. 2014. Domestication and brood stock development of the orange spotted grouper, Epinephelus coioides (Hamilton, 1822) in open sea cage off Visakhapatnam coast. Indian. J. Fish., 61(1): 21-25.

Sajidkhan I. Y. and Hukam Singh 2005. Rearing of Penaeus monodon (Fabricius) post-larvae in floating cages at different stocking densities. Aquac. Res., 36: 405-408. doi: 10.1111/j. 1365-2109.2005.01216. x

Shanmugam, A., John Peter, Selvamani and Kannupandi, T. 1994. Prospects and problems in cage culture of giant tiger shrimp in Vellar Estuary. Curr. Sci., 67(8): 612-613.

Sílvio Peixoto, Diogo Luiz, De Alcantara Lopes and Wilson Wasielesky 2013. Estuarine cage culture of pink shrimp Farfantepenaeus brasiliensis at different stocking densities. J. Shellfish Res., 32(2): 559-563.

Sivanandavel, P. and Soundarapandian, P. 2013a. Influence of cage shapes on growth, survival and production of white shrimp Penaeus indicus (H. Milne Edwards) in Vellar Estuary. 2: 588 pp. doi: 10.4172/scientific reports. 588 .

Sivanandavel, P. and Soundarapandian, P. 2013b. Cage erection and hideouts on growth, survival and production of Indian white shrimp, Penaeus indicus (H. Milne Edwards) in Vellar Estuary. 2: 589 pp. doi: 10.4172/scientific reports. 589

Snedecor, G. W. and Cochran, W. G. 1980. Statistical methods, Oxford \& IBH Publishing Co., New Delhi. 593 pp.

Suresh Kumar, M., Imelda Joseph, Maheswarudu, G., Ritesh Ranjan, Biswajit Dash, Shubhadeep Ghosh and Syda Rao, G. 2012. Open sea mariculture of Asian seabass Lates calcarifer (Bloch, 1790) in marine floating cage at Balasore, Odisha, North-east coast of India. Indian J. Fish., 59(3): 89-93.

Zolarzano, L. 1969. Determination of ammonia in natural waters by the phenol hypochlorite method. Limnol. Oceanogr., 14(5): 799-801. 